\title{
Photodynamic therapy in the treatment of onychomycosis
} - a review

\section{Terapia fotodynamiczna w leczeniu grzybicy paznokci - przegląd piśmiennictwa}

\author{
Katarzyna Kalinowska, Anita Hryncewicz-Gwóźdź
}

Department of Dermatology, Venerology and Allergology, Wroclaw Medical University, Wroclaw, Poland

Katedra i Klinika Dermatologii, Wenerologii i Alergologii Uniwersytetu Medycznego we Wrocławiu, Wrocław, Polska

Dermatol Rev/Przegl Dermatol 2017, 104, 290-299

DOI: https://doi.org/l0.5 | |4/dr.20 I7.68776

\author{
CORRESPONDING AUTHOR/ \\ ADRES DO KORESPONDENCJI: \\ dr n. med. Katarzyna Kalinowska \\ Katedra i Klinika Dermatologii, \\ Wenerologii i Alergologii \\ Uniwersytet Medyczny \\ we Wrocławiu \\ ul. Chałubińskiego 1 \\ 50-308 Wrocław, Polska \\ tel.: +48504 498694 \\ e-mail: kj.kalinowska@gmail.com
}

\begin{abstract}
Toenail onychomycosis is a common infection, affecting up to $14 \%$ of the population. Moreover, poor penetration of topical drugs into the nail bed leads to frequent recurrences of the disease. The cure rate of toenail onychomycosis is estimated at $63-76 \%$. An alternative treatment for onychomycosis is photodynamic therapy. Following agents are used in this method: porfimer sodium, rose bengal, methylene blue, 5-aminolevulinic acid and its derivative - methyl ester. The therapy is well tolerated Photodynamic therapy offers an opportunity to achieve a significant cure rate in patients who cannot receive oral therapy. Thanks to systematic improvements in photodynamic therapy, including better photosensitizer penetration into the nail bed and shorter exposure time, photodynamic therapy may be more efficient and cost-effective than other onychomycosis treatments. However, randomized clinical trials evaluating the efficacy of photodynamic therapy of onychomycosis are needed.
\end{abstract}

\section{STRESZCZENIE}

Grzybica paznokci stóp jest częstym zakażeniem, może dotyczyć do $14 \%$ populacji. Ponadto utrudnione przenikanie substancji leczniczych do łożyska paznokcia w leczeniu miejscowym powoduje częste nawroty schorzenia. Szacuje się, że odsetek wyleczeń grzybicy paznokci stóp wynosi $63-76 \%$. Terapia fotodynamiczna stanowi alternatywną metodę leczenia grzybicy paznokci. W tym zabiegu wykorzystuje się następujące substancje: porfimer sodu, róż bengalski, błękit metylenowy, kwas 5-aminolewulinowy oraz jego pochodną - ester metylowy. Leczenie jest dobrze tolerowane przez pacjentów. Dzięki zastosowaniu terapii fotodynamicznej można uzyskać znaczny odsetek wyleczeń wśród pacjentów, którzy nie mogą przyjmować terapii doustnej. Dzięki systematycznemu ulepszaniu terapii fotodynamicznej związanemu z lepszą penetracją fotouczulacza do łożyska paznokcia czy też ze skróceniem czasu naświetlania może być ona bardziej wydajna i kosztować mniej w porównaniu z innymi metodami leczenia onychomykozy. Konieczne są jednak randomizowane badania kliniczne oceniające skuteczność leczenia grzybicy paznokci za pomocą terapii fotodynamicznej.

Key words: onychomycosis, photodynamic therapy, 5-aminolevulinic acid.

Słowa kluczowe: onychomykoza, terapia fotodynamiczna, kwas 5-aminolewulinowy. 
Onychomycosis is a fungal infection of the nail caused by dermatophytes, yeast-like and mould fungi. The big toe is usually the first nail to be affected, and with time the infection may spread to other nails. Onychomycosis may produce considerable discomfort for the patient, both physical (pain, problems with mobility) and psychological (reluctance to wear open-toe footwear, avoidance of swimming pools and saunas), significantly lowering the quality of life [1, 2].

Toenail onychomycosis is classified into five types, the most common type being distal and lateral subungal onychomycosis (DLSO). Fungal infection can be confirmed by mycological examination including direct (microscopic) evaluation, culture test on Sabouraud's agar or rapid and sensitive polymerase chain reaction (PCR) assay. In addition, histopathological examination of nail clippings using PAS staining may be performed in diagnostically difficult cases, however the method is rarely used and fails to determine the types of pathogens which are responsible for the fungal infection [1-3].

It is estimated that onychomycosis may affect up to $14 \%$ of the population. Factors contributing to an increase in incidence include the growing rate of diabetes, ageing of the society and therapy with immunosuppressive drugs. Toenail onychomycosis occurs more often in men than in women, and 30 times more often in adults than in children. The main aetiological factor of the disease is the dermatophyte Trichophyton rubrum, and much less commonly - Trichophyton mentagrophytes. The treatment of toenail onychomycosis is difficult because of the slow growth of the nail plate, need to use antifungal agents on a prolonged basis and increasing microbial resistance to drugs. Furthermore, the disease recurs frequently, as spores are able to survive for example in the footwear $[1,4]$.

A metaanalysis evaluating the mycological cure rate in toenail onychomycosis showed that the highest cure rate, even up to $76 \%$, was achieved with oral terbinafine. Itraconazole was found to be less effective, with the cure rate of $63 \%$ [5]. Oral antifungal therapy, however, has a number of contraindications and cannot be used in patients with a history of internal diseases. An alternative in the current treatment standard is the chemical or mechanical removal of the affected nail plate followed by topical or oral treatment in cases of severe recurrent infections [6].

In consideration of growing drug resistance observed among the fungi triggering superficial infections of the skin and its appendages, the search is on for new therapeutic methods. One of them is photodynamic therapy (PDT). Photodynamic ther-

\section{WSTĘP}

Onychomykoza to zakażenie grzybicze paznokci wywołane przez dermatofity, grzyby drożdżopodobne i grzyby pleśniowe. Początkowo zmiany chorobowe pojawiają się zazwyczaj na paznokciu palucha, z czasem mogą zostać zajęte pozostałe paznokcie. Pacjenci mogą odczuwać znaczny dyskomfort: fizyczny (ból, trudności z poruszaniem się) oraz psychiczny (niechęć do zakładania odkrytego obuwia, unikanie basenów oraz saun), co znacząco obniża jakość życia [1, 2].

Wśród pięciu podtypów grzybicy paznokci stóp odmiana dystalno-boczna (distal and lateral subungal onychomycosis - DLSO) jest obserwowana najczęściej. Aby potwierdzić zakażenie grzybicze, należy wykonać badanie mykologiczne, w tym badanie bezpośrednie (mikroskopowe), badanie hodowlane na podłożu Sabourauda, lub też szybkie oraz czułe badanie metodą łańcuchowej reakcji polimerazy (polymerase chain reaction - PCR). W przypadku trudności diagnostycznych można wykonać dodatkowo barwienie histopatologiczne (PAS) wycinków paznokci, jednak jest to metoda dość rzadko stosowana i nie daje odpowiedzi, jakie patogeny wywołały zakażenie grzybicze [1-3].

Szacuje się, że onychomykoza może dotyczyć aż do $14 \%$ populacji. Do zwiększenia częstości jej występowania przyczynia się wzrost odsetka ludzi chorujących na cukrzycę, starzejące się społeczeństwo oraz przyjmowanie leków immunosupresyjnych. Grzybica paznokci stóp jest częściej obserwowana u mężczyzn niż u kobiet i 30 razy częściej u dorosłych niż u dzieci. Głównym czynnikiem etiologicznym grzybicy paznokci stóp jest dermatofit Trichophyton rubrum, o wiele rzadziej Trichophyton mentagrophytes. Leczenie grzybicy paznokci stóp jest trudne, gdyż wiąże się z wolnym wzrostem płytki paznokciowej, koniecznością długiego stosowania preparatów przeciwgrzybiczych oraz zjawiskiem narastania lekooporności wśród mikroorganizmów. Ponadto bardzo często dochodzi do nawrotów choroby ze względu na przeżywalność zarodników na przykład w obuwiu $[1,4]$.

Metaanaliza oceniająca odsetek wyleczeń mykologicznych w przypadku grzybicy paznokci stóp wykazała, że najwyższy odsetek wyleczeń, sięgający nawet $76 \%$, uzyskano po zastosowaniu doustnie terbinafiny. Mniej skuteczne okazało się leczenie itrakonazolem, w tym przypadku odsetek wyleczeń wynosił 63\% [5]. Jest jednak wiele przeciwwskazań do leczenia preparatami doustnymi i nie można ich stosować u pacjentów obciążonych internistycznie. Alternatywą w obecnym standardzie leczenia jest chemiczne lub mechaniczne usuwanie zmienionej chorobowo płytki paznokciowej i włączenie leczenia miejscowego bądź doustnego w przypadku ciężkich, nawracających infekcji [6].

Wzrastająca lekooporność grzybów wywołujących powierzchowne zakażenia skóry i jej przydatków skłania do poszukiwania innych metod leczenia, np. 
apy is a therapeutic modality which involves the application of a photosensitizing agent and a light source emitting a beam with an appropriate wavelength. The core of the process is the formation of reactive oxygen species or singlet oxygen (depending on the presence of aerobic/anaerobic conditions) which affect fungal cells causing, for example, changes in cell membrane permeability or DNA fragmentation and ultimately leading to cytotoxicity and cell death by apoptosis or necrosis. Benefits of PDT include high selectivity, reduced adverse effects and high safety. The therapy may be used in patients with a history of internal diseases who cannot use oral antifungal drugs $[7,8]$.

There is a wide range of photosensitizers which can be employed in PDT. Photodynamic therapy photosensitizers belong to three families - porphyrins, chlorophylls and dyes - and are widely used in medicine. Some photosensitizing agents which are employed for PDT include 5-aminolevulinic acid (5-ALA), 5-aminolevulinic acid methyl ester (MAL), methylene blue, rose bengal or porfimer sodium. The most commonly used photosensitizer in dermatological applications is 20\% 5-aminolevulinic acid solution [8].

At present PDT can be used in the treatment of other skin conditions including acne, actinic keratosis, skin cancer (excluding melanoma), hidradenitis suppurativa and sebaceous gland hyperplasia. In addition, PDT is suitable for skin rejuvenation procedures [9].

Photodynamic therapy procedures are performed with dye lasers pumped by argon or neodymium lasers, gold and copper vapour lasers as well as LED lasers and OLED systems. The popularity of the latter has been growing recently, as the devices are relatively cost-efficient and compact in size, and offer the possibility to irradiate a precisely defined skin area. The photosensitizing substance may become activated by one or several types of applied light. The optimum beam wavelength depends on the molecular structure of the substance used for therapy and the type of tissue treated by PDT. The basic rule of photobiology states that the longer the wavelength, the deeper the penetration into the tissue. Since the human skin is easily accessible to light, PDT offers greater opportunities and enables the use of a wider wavelength range $[10,11]$.

\section{PHOTODYNAMIC THERAPY WITH 5-AMINOLEVULINIC ACID}

\section{5-aminolevulinic acid: structure and biological properties}

5-aminolevulinic acid (5-ALA) is an amino derivative of levulinic acid belonging to the group of keto z wykorzystaniem terapii fotodynamicznej (photodynamic therapy - PDT). Polega ona na aplikacji substancji fotouczulającej (sensybilizatora) oraz źródła światła emitującego wiązkę o odpowiedniej długości fali. Istotą procesu jest powstanie reaktywnej formy tlenu bądź tlenu singletowego (w zależności od warunków - aerobowych lub anaerobowych), które oddziałują na komórki grzybicze, powodując m.in. zmiany w przepuszczalności błon komórkowych bądź fragmentację DNA, co prowadzi do efektu cytotoksycznego i obumierania komórek na drodze apoptozy lub nekrozy. Zaletami PDT są duża selektywność, mniej efektów ubocznych i duże bezpieczeństwo. Terapia ta może być również stosowana u pacjentów obciążonych internistycznie, którzy nie mogą przyjmować leków przeciwgrzybiczych doustnie [7, 8].

Dostępny jest szeroki zakres fotouczulaczy do PDT. Pochodzą one z trzech rodzin - porfiryn, chlorofili i barwników - i są szeroko stosowane w medycynie. W praktyce klinicznej do PDT stosuje się m.in.: kwas 5-aminolewulinowy (5-ALA), ester metylowy kwasu 5-aminolewulinowego (MAL), błękit metylenowy, róż bengalski czy porfimer sodu. W dermatologii najczęściej używa się 20-procentowego roztworu kwasu 5-aminolewulinowego [8].

Obecnie dzięki PDT można również leczyć inne schorzenia dermatologiczne, takie jak trądzik, rogowacenie słoneczne, nowotwory skóry (z wyłączeniem czerniaka), ropne zapalenie gruczołów potowych, przerost gruczołów łojowych. Metoda ta jest stosowana również w zabiegach odmładzania skóry [9].

Do naświetlania wykorzystuje się lasery barwnikowe pompowane laserami argonowymi lub neodymowymi, lasery na parach złota i miedzi, a także lasery diodowe oraz systemy diodowe (LED i OLED). Zastosowanie tych ostatnich wzrasta ze względu na stosunkowo niski koszt, małe rozmiary urządzenia czy możliwość naświetlania ściśle określonej powierzchni. Jeden lub kilka rodzajów światła może aktywować substancję - fotouczulacz. Optymalna długość wiązki światła zależy od budowy molekularnej substancji używanej w terapii oraz od rodzaju tkanki, jaka jest poddawana PDT. Podstawowa zasada fotobiologii jest taka, że im długość fali jest większa, tym przenikanie w głąb tkanki większe. Ponieważ ludzka skóra jest łatwo dostępna dla światła, zastosowanie PDT daje większe możliwości i można stosować szerszy zakres długości fali [10, 11].

\section{TERAPIA FOTODYNAMICZNA Z UŻYCIEM KWASU 5-AMINOLEWULINOWEGO}

\section{Kwas 5-aminolewulinowy - budowa i właściwości biologiczne}

Kwas 5-aminolewulinowy (5-ALA) jest aminową pochodną kwasu lewulinowego, należy do grupy 


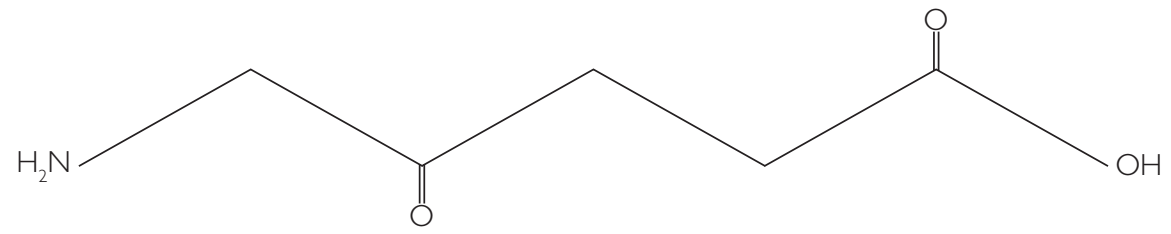

Rycina I. Cząsteczka kwasu 5-aminolewulinowego

Figure I. Molecule of 5-aminolevulinic acid

acids and amino acids. It is the first compound involved in the porphyrin biosynthesis pathway which leads to the formation of haem in mammals and chlorophyll in plants (Fig. 1).

5-ALA is an endogenous acid (occurring naturally in the body) which is involved in the biosynthesis of haem. The rate of haem biosynthesis can be regulated by two methods. One of them is the synthesis of aminolevulinic acid from glycine and succinyl-CoA catalyzed by synthase. The reaction itself is regulated via negative feedback, with the reaction product inhibiting the process that produces it. The other method is the ferrochelatase-catalysed reaction in which an iron ion is inserted into a protoporphyrin IX (PpIX) molecule to form haem. Exogenous administration of 5-ALA bypasses the first stage of haem synthesis. Protoporphyrin IX accumulates in the cellular mitochondria, which is used in PDT. Combined with a light source with a wavelength corresponding to the absorption maximum of the photosensitizing substance, the process gives rise to reactive oxygen species triggering cell death $[12,13]$.

Photodynamic therapy requires three components: a photosensitizer, oxygen and light source. Following its incorporation into cells, the photosensitizer is irradiated with light at a wavelength corresponding to its absorption maximum, undergoing transition from the ground state to the excited singlet state. Further conversion into the triplet state allows the photosensitizer to transfer excitation energy to the oxygen molecule. Triplet oxygen $\left({ }^{3} \mathrm{O}_{2}\right)$ dissolved in cell fluids is then converted into singlet oxygen $\left({ }^{1} \mathrm{O}_{2}\right)$, and the photosensitizer returns to its ground (non-excited) state. Among reactive oxygen species (ROS) arising during photodynamic reaction singlet oxygen is believed to play a dominant role in toxic effects of PDT. In anaerobic conditions - or when the oxygen concentration is reduced - the photooxidation reaction takes place through the formation of free radical forms such as the peroxide radical (ROO*) and the superoxide anion $\left(\mathrm{O}_{2}{ }^{--}\right)$which initiate the process of destruction of pathologically altered tissue. The identification of the dominant mechanism during the process is a challenging task [14, 15]. The photosensitizer used in PDT is excited by a light beam with an appropriate wave- ketokwasów i aminokwasów. Jest pierwszym związkiem w szlaku biosyntezy porfiryn, który u ssaków prowadzi do powstania hemu, a u roślin - chlorofilu (ryc. 1).

5-ALA jest aminokwasem endogennym (naturalnie występującym w organizmie), który bierze udział w biosyntezie hemu. Szybkość biosyntezy hemu może być regulowana na dwa sposoby. Pierwszym jest synteza kwasu aminolewulinowego z glicyny i bursztynylo-CoA, którą katalizuje syntaza. Sama reakcja jest regulowana przez ujemne sprzężenie zwrotne - produkt reakcji hamuje proces. Drugim sposobem jest reakcja katalizowana przez ferrochelatazę, polegająca na włączeniu jonu żelaza do cząsteczki protoporfiryny IX (PpIX), która prowadzi do powstania hemu. Egzogenne podanie 5-ALA prowadzi do ominięcia pierwszego etapu syntezy hemu. W komórce, w mitochondriach dochodzi do gromadzenia PpIX, co wykorzystuje się w PDT. W połączeniu ze źródłem światła o długości fali odpowiadającej maksimum absorpcji dla substancji fotoczułej w procesie tym wytwarzają się reaktywne formy tlenu, które powodują obumieranie komórki $[12,13]$.

Do przeprowadzenia PDT niezbędne są trzy składniki - fotouczulacz, tlen oraz źródło światła. Fotouczulacz po wprowadzeniu do komórek jest naświetlany światłem o długości fali odpowiadającej maksimum jego absorpcji i przechodzi ze stanu podstawowego w singletowy stan wzbudzony. Dalsze przejście do stanu trypletowego powoduje, że fotouczulacz może przekazać energię wzbudzenia na cząsteczkę tlenu. Wówczas tlen trypletowy $\left({ }^{3} \mathrm{O}_{2}\right)$ rozpuszczony w płynach komórkowych przechodzi w tlen singletowy $\left({ }^{1} \mathrm{O}_{2}\right)$, fotouczulacz z kolei powraca do stanu podstawowego (niewzbudzonego). Uważa się, że wśród tzw. reaktywnych form tlenu (RFT) powstających w czasie reakcji fotodynamicznej tlen singletowy ma dominujące znaczenie w toksycznych efektach PDT. W warunkach anaerobowych lub gdy stężenie tlenu jest zmniejszone, reakcja fotoutleniania przebiega przez wytworzenie form wolnorodnikowych, takich jak rodnik nadtlenkowy (ROO') i anion ponadtlenkowy $\left(\mathrm{O}_{2}{ }^{--}\right)$, które rozpoczynają niszczenie zmienionej chorobowo tkanki. Rozróżnienie mechanizmu dominującego w czasie tego procesu jest trudne [14, 15]. W PDT fotouczulacz wzbudzany jest wiązką o odpowiedniej 
length, which determines the extent of the therapeutic effects. To achieve the most effective light absorption for the human tissue, the light source should be in the red light spectrum, that is at wavelengths above $630 \mathrm{~nm}$. Light at a wavelength of $630 \mathrm{~nm}$ penetrates the tissue to a depth of approximately $0.5 \mathrm{~cm}$, but above $700 \mathrm{~nm}$ the depth of tissue penetration is about $1.5 \mathrm{~cm}$. In photodynamic diagnostics (PDD) fluorescence is induced by light at shorter wavelengths, in the range of approximately $375-400 \mathrm{~nm}$. For example, in cancer treatment it is crucial that the photosensitizer achieves a higher concentration in pathologically altered tissue, particularly affected by cancer, than in healthy tissues, which is due to its denser vasculature and poorer lymphatic drainage. After its accumulation in the affected tissue, the photosensitizer shows red fluorescence in the range of $635-700 \mathrm{~nm}$. In contrast, healthy tissues emit green fluorescence (so-called autofluorescence) with a wavelength of about $500 \mathrm{~nm}$ due to compounds which are naturally present in body cells. The irradiation technique used in PDT depends on the type of photosensitizer and the target tissue to be treated by PDT. For example, deep changes are irradiated using optical fibres [16].

\section{Aminolevulinic acid in the literature}

Recent years have seen several publications discussing the application of PDT in the treatment of toenail onychomycosis caused by dermatophytes or yeast-like fungi.

Donnelly et al. were the first to investigate the therapeutic properties of 5-ALA under in vitro conditions. The publication describes the effect of the photosensitizer on the count and survival of colonies of yeast fungi (Candida albicans) and dermatophytes (Trichophyton interdigitale).

In the study of Candida albicans, the authors achieved the best results by incubating cells for $30 \mathrm{~min}$ with $100 \mathrm{mM}$ solution of 5-ALA and irradiating them with a light beam with a wavelength of $635 \mathrm{~nm}$. The survival of yeast cells was shown to be only $6 \%$ compared to the non-irradiated control.

In the analysis of the dermatophyte fungi Trichophyton interdigitale the best results were obtained after incubating spores in $100 \mathrm{mM}$ solution of 5-ALA and extending the incubation period to $6 \mathrm{~h}$. In this case the spore survival rate was $21 \%$ compared to the non-irradiated control [17].

Similarly to Donelly et al., Kamp et al. conducted in vitro studies of the effect of PDT using 5-ALA on the growth rate and survival of the species Trichophyton rubrum. At the outset, the authors determined through an evaluation of specimens by fluorescent microscopy in what conditions (5ALA concentration, incubation time) the greatest amount of PpIX formed in the mycelium hyphae długości fali, co wpływa na efekty terapeutyczne. Najbardziej efektywna dla ludzkiej tkanki jest absorpcja światła ze spektrum światła czerwonego, czyli o długości fali powyżej $630 \mathrm{~nm}$. Światło o długości fali $630 \mathrm{~nm}$ penetruje tkankę na głębokość ok. $0,5 \mathrm{~cm}$, z kolei światło o długości fali powyżej $700 \mathrm{~nm}$ penetruje tkankę na głębokość ok. 1,5 cm. W diagnostyce fotodynamicznej (photodynamic diagnostic - PDD) fluorescencję wywołuje się światłem o mniejszych długościach fal - w zakresie ok. 375-400 nm. Przykładowo w leczeniu nowotworów istotne jest, że fotosensybilizator osiąga większe stężenie w tkance chorobowo zmienionej, szczególnie nowotworowej, niż w tkankach zdrowych. Wynika to z jej bogatszego unaczynienia i uboższego drenażu limfatycznego. Fotouczulacz po rozmieszczeniu w chorej tkance fluoryzuje na czerwono w zakresie 635-700 nm, natomiast zdrowe tkanki emitują wówczas zieloną fluorescencję (tzw. autofluorescencję) o długości fali ok. $500 \mathrm{~nm}$, pochodzącą od związków naturalnie występujących w komórkach. Technika naświetlania wykorzystywana w PDT zależy od typu fotouczulacza oraz docelowej tkanki. Na przykład zmiany głębokie naświetla się za pomocą włókien światłowodowych [16].

\section{Kwas aminolewulinowy w piśmiennictwie}

W ciągu ostatnich lat pojawiło się kilka publikacji dotyczących zastosowania PDT w leczeniu grzybicy paznokci stóp spowodowanej przez grzyby dermatofitowe czy też drożdżopodobne.

Donnelly i wsp. po raz pierwszy zbadali terapeutyczne właściwości 5-ALA w warunkach in vitro. W publikacji opisują m.in. wpływ fotouczulacza na liczność i przeżywalność kolonii grzybów drożdżakowych (Candida albicans) oraz grzybów dermatofitowych (Trichophyton interdigitale).

W przypadku Candida albicans autorzy uzyskali najlepsze rezultaty, inkubując komórki przez $30 \mathrm{~min}$ z roztworem 5-ALA o stężeniu 100 mM i naświetlając wiązką światła o długości $635 \mathrm{~nm}$. Wykazano, że przeżywalność komórek drożdżakowych wynosiła zaledwie $6 \% \mathrm{w}$ porównaniu z nienaświetlaną kontrolą.

Z kolei w przypadku grzyba dermatofitowego Trichophyton interdigitale najlepsze rezultaty również uzyskano, inkubując zarodniki z roztworem 5-ALA o steżeniu $100 \mathrm{mM}$ oraz wydłużając czas inkubacji do 6 godzin. W tym przypadku przeżywalność zarodników wynosiła $21 \%$ w porównaniu z nienaświetlaną kontrolą [17].

Kamp i wsp., podobnie jak Donelly i wsp., wykonali badania in vitro dotyczące wpływu PDT z użyciem 5-ALA na wzrost i przeżywalność gatunku Trichophyton rubrum. Początkowo autorzy określili za pomocą obserwacji preparatów w mikroskopie fluorescencyjnym, w jakich warunkach (stężenie kwasu 5-ALA, czas inkubacji) w strzępkach grzybni wytwa- 
after the exposure of the microorganism to the photosensitizer. In the next stage, liquid cultures of T. rubrum were incubated with 5-ALA solution in pre-established conditions and inoculated into Petri dishes with a solid medium. One half of the dish was additionally irradiated with light emitted by a quartz-halogen lamp and the other half was not irradiated (control). The plates were incubated for seven days. The authors demonstrated at least $50 \%$ inhibition of mycelial growth (reduced number and smaller diameter of colonies) on the plate subjected to PDT with 5-ALA compared to the control [18].

Piraccini et al. reported a case of curing toenail onychomycosis caused by T. rubrum with PDT. As the first step of treatment, the nail plates were softened using $40 \%$ urea solution and then treated with $20 \%$ solution of 5 -ALA. Irradiation was performed using a LED light source with a wavelength of $630 \mathrm{~nm}$. The intervals between consecutive PDT treatments were 15 days. In total, the patient completed 3 PDT sessions and the treatment lasted 45 days. Three months after the completion of therapy a mycological follow-up examination was carried out. The result was negative both microscopically and by culture [19].

The publication by Watanabe et al. presents two cases of curing toenail onychomycosis by ALA-PDT. As in the study by Piraccini et al., pathologically altered nails were first softened using 20\% urea solution in order to improve the penetration of the active ingredient into the nail bed. The therapy was based on $20 \%$ solution of 5-ALA and a dye laser emitting a light beam with a wavelength of $630 \mathrm{~nm}$ as the light source. In the first case, the patient underwent seven PDT sessions, and in the second case - six PDT sessions. In both cases the results of mycological examination (direct assessment and culture) were negative after the completion of treatment [20].

Soritiou et al. studied the treatment of onychomycosis caused by T. rubrum by PDT with 5-ALA in a group of 30 patients (20 men, 10 women) with positive results of direct mycological examinations and culture tests. Similarly to the publication cited above, pathologically altered nails were softened with $20 \%$ urea solution. The treatment consisted of $20 \%$ solution of 5 -ALA and irradiation with red light at a wavelength of 570-670 nm. The intervals between consecutive PDT sessions were 14 days, and every patient received three PDT treatments. Out of 30 patients, $13(43.3 \%)$ were found to be clinically and mycologically cured a year after the end of PDT. Among 13 cured patients, two exhibited mild lesions on the nail plates (despite negative mycological results) 18 months after the completion of photodynamic rza się najwięcej PpIX po ekspozycji mikroorganizmu na fotouczulacz. W kolejnym etapie płynne hodowle T. rubrum inkubowano z roztworem 5-ALA w warunkach ustalonych wcześniej, a następnie wysiano na płytki Petriego zawierające podłoże stałe, przy czym jedna połowa szalki była dodatkowo naświetlana źródłem światła pochodzącym z lampy kwarcowo-halogenowej, a druga połowa szalki nie była naświetlana (kontrola). Płytki były inkubowane przez 7 dni. Autorzy wykazali przynajmniej 50-procentowe zahamowanie wzrostu grzybni (zredukowana liczba kolonii, mniejsza średnica kolonii) na płytce po PDT z użyciem 5-ALA w porównaniu z kontrolą [18].

Piraccini i wsp. opisali przypadek wyleczenia za pomocą PDT grzybicy paznokci stóp spowodowanej przez T. rubrum. Płytki paznokciowe początkowo zostały zmiękczone za pomocą 40-procentowego roztworu mocznika, a następnie potraktowane 20-procentowym roztworem 5-ALA. Do naświetlania użyto źródła światła LED o długości fali $630 \mathrm{~nm}$. Interwały pomiędzy kolejnymi terapiami fotodynamicznymi wynosiły 15 dni. W sumie pacjentka odbyła 3 sesje PDT, a leczenie trwało 45 dni. Po 3 miesiącach od zakończenia terapii wykonano kontrolne badanie mykologiczne, którego wynik był ujemny zarówno pod mikroskopem, jak i w hodowli [19].

W publikacji Watanabe i wsp. przedstawione są dwa przypadki wyleczenia grzybicy paznokci stóp za pomocą ALA-PDT. Autorzy, podobnie jak w publikacji Piraccini i wsp., początkowo zmiękczyli chorobowo zmienione paznokcie 20-procentowym roztworem mocznika, aby uzyskać lepszą penetrację substancji czynnej do łożyska paznokcia. W leczeniu zastosowano 20-procentowy roztwór 5-ALA, a jako źródło światła wykorzystano laser barwnikowy emitujący wiązkę światła o długości $630 \mathrm{~nm}$. Pierwszą pacjentkę poddano PDT siedmiokrotnie, drugą - sześciokrotnie. W obu przypadkach wynik badania mykologicznego (bezpośrednie oraz hodowlane) był ujemny po zakończeniu leczenia [20].

Soritiou i wsp. przeprowadzili badania nad leczeniem onychomikozy wywołanej przez T. rubrum za pomocą PDT z wykorzystaniem 5-ALA u 30 pacjentów (20 mężczyzn, 10 kobiet) z dodatnim wynikiem bezpośredniego badania mykologicznego oraz hodowlanego. Podobnie jak w poprzedniej publikacji, paznokcie zmienione chorobowo zmiękczono 20-procentowym roztworem mocznika. W terapii zastosowano 20-procentowy roztwór 5-ALA, a do naświetlania użyto światła czerwonego w zakresie długości fali 570-670 nm. Interwały pomiędzy kolejnymi PDF wynosiły 14 dni, a każdy z pacjentów odbył 3 sesje terapii. Spośród 30 pacjentów u 13 (43,3\%) stwierdzono wyleczenie kliniczne oraz mykologiczne po roku od zakończenia PDT. U 2 pacjentów spośród 13 wyleczonych 18 miesięcy po zakończeniu PDT zaobserwowano niewielkie zmiany na płytkach paznok- 


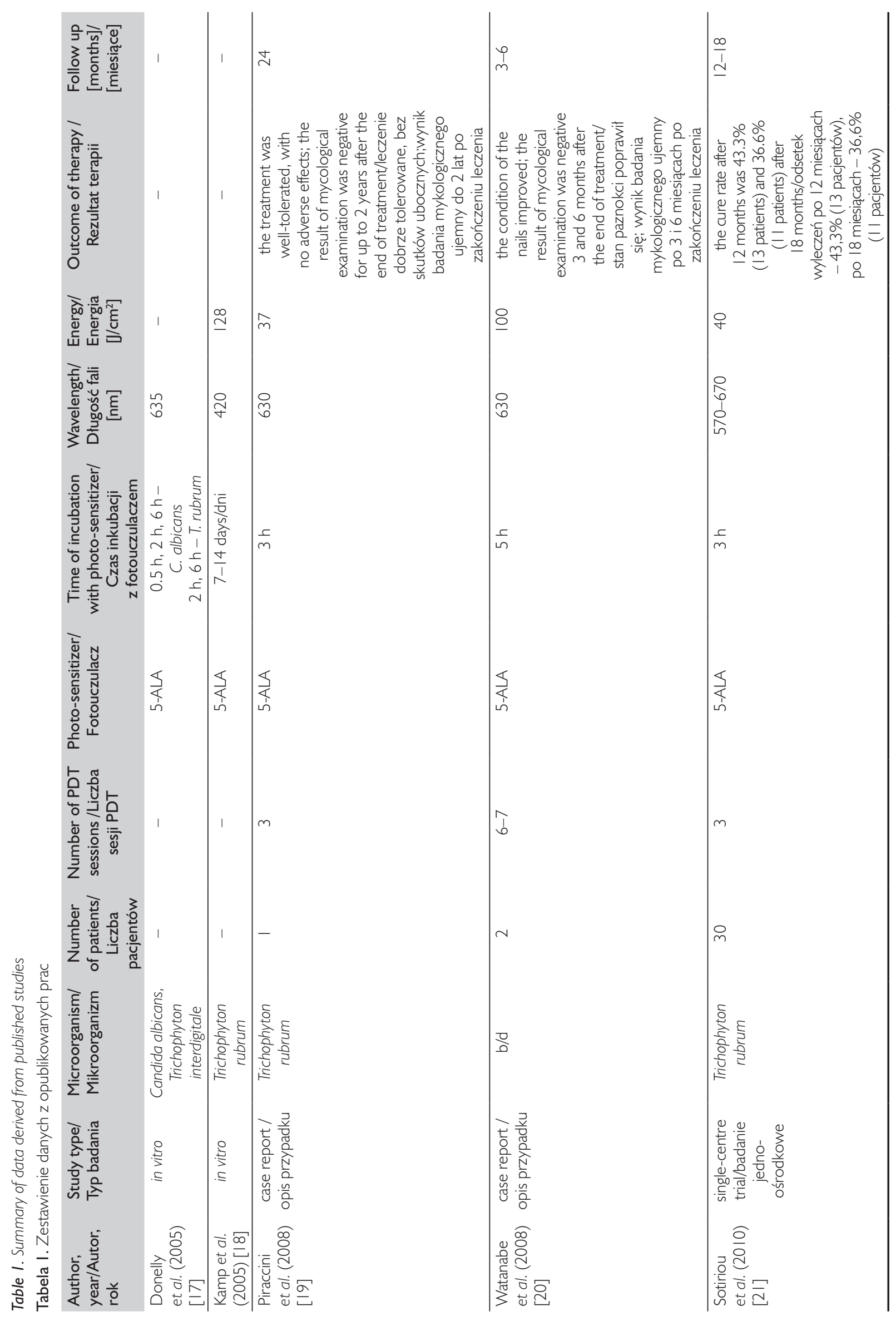


therapy. No pathological nail plate lesions were identified in the remaining 11 (36.6\%) patients [21].

The findings of the publications presented above are listed in Table 1.

\section{DISCUSSION}

Photodynamic therapy is based on the effect of light and photosensitizing agents. It is an established method of treating precancerous states and selected skin cancers. Recent years have also seen a number of reports describing the application of the method for the treatment of certain inflammatory skin diseases. The cytotoxic effect of the photodynamic method is attributable to the selective cellular accumulation of the photosensitizer which, in response to irradiation with light at an appropriate wavelength, undergoes transition to the excited state with the release of singlet oxygen and peroxide free radicals. The process of photooxidation leads to the destruction of cells by apoptosis or necrosis. The biological mechanism which underlies the photodynamic effect on fungal cells is multifaceted, which significantly reduces the risk of formation of PDT-resistant strains and lowers the risk of mutagenic effects for the fungi. At present, attempts are undertaken to determine the concentrations of photosensitizers, incubation times and irradiation doses necessary to eradicate (destroy) fungal cells in vitro. There have been limited reports on the application of the method in the treatment of fungal infections in humans. Owing to limited adverse effects and absence of the problem of growing resistance, the method seems to be a good therapeutic alternative in patients not responding to treatment with antifungal medicines [15].

According to estimates onychomycosis affects up to $14 \%$ of the general population, which makes it a very common condition [22]. Fungal infections are most often caused by dermatophytes and occasionally also mould and yeast-like fungi. There are a number of factors predisposing to the disease, including hyperhidrosis, occlusive footwear, certain types of sport, SPA treatments and swimming pool use - as well as nail injuries, immune deficiencies, diabetes and elderly age. There are a number of methods of treating onychomycosis including topical lacquers, ointments, oral antifungal drugs, and surgical and chemical nail plate removal. Recently, attention has also been focused on the possibilities of applying PDT in the treatment of mycosis [23, 24].

It is an interesting alternative because of minimal systemic adverse reactions and relatively short duration of therapy. The majority of studies published to date are case reports about the use of PDT in the treatment of toenail onychomycosis. The authors of the studies discussed above indicate that PDT was ciowych pomimo ujemnych wyników badań mykologicznych. U pozostałych $11(36,6 \%)$ pacjentów nie obserwowano zmian chorobowych w obrębie płytek paznokciowych [21].

Wyniki badań opisanych powyżej umieszczono w tabeli 1.

\section{OMÓWIENIE}

Terapia fotodynamiczna jest metodą, która opiera się na działaniu światła oraz związków fotouczulających. Jest uznanym sposobem leczenia stanów przedrakowych oraz wybranych nowotworów skóry. W ostatnich latach pojawiły się również liczne doniesienia o stosowaniu tej metody w niektórych zapalnych chorobach skóry. Efekt cytotoksyczny metody fotodynamicznej wiąże się z selektywnym gromadzeniem w komórkach fotouczulacza, który po naświetlaniu światłem o odpowiedniej długości fali przechodzi w stan pobudzenia z uwalnianiem tlenu singletowego i wolnych rodników nadtlenkowych. W następstwie fotoutleniania dochodzi do niszczenia komórek na drodze apoptozy bądź nekrozy. Biologiczny mechanizm działania fotodynamicznego na komórki grzybów jest wielokierunkowy, co zasadniczo redukuje ryzyko powstania szczepów opornych na PDT i zmniejsza ryzyko efektu mutagennego dla grzybów. Obecnie podejmuje się próby ustalenia stężeń fotouczulaczy, czasów inkubacji oraz dawek światła potrzebnych do zniszczenia (zabicia) komórek grzybów in vitro. Pojawiły się nieliczne doniesienia o leczeniu tą metodą grzybiczych infekcji skóry u ludzi. Wydaje się, że ze względu na niewielką liczbę działań niepożądanych oraz brak narastania oporności PDT może być alternatywą w przypadkach niereagujących na leki przeciwgrzybicze [15].

Grzybica paznokci jest wyjątkowo częstym problemem. Szacuje się, że może ona dotyczyć aż do $14 \%$ populacji [22]. Zakażenie grzybicze najczęściej wywołują dermatofity, czasami też grzyby pleśniowe i drożdżopodobne. Wiele czynników predysponuje do wystąpienia choroby - nadmierne pocenie się, noszenie okluzyjnego obuwia, uprawianie niektórych rodzajów sportu, uczęszczanie do SPA i korzystanie z basenów, urazy paznokci, niedobory odporności, cukrzyca, podeszły wiek. Znanych jest wiele metod leczenia onychomykozy, m.in. miejscowe lakiery, maści, doustne leki przeciwgrzybicze, chirurgiczne i chemiczne usuwanie płytki paznokciowej. Ostatnio zwraca się uwagę na możliwość wykorzystania PDT w leczeniu grzybicy [23, 24].

Jest to interesująca alternatywa ze względu na minimalne ogólnoustrojowe działania niepożądane i dość krótki czas terapii. Większość badań opublikowanych do tej pory to głównie opisy przypadków zastosowania PDT w leczeniu grzybicy paznokci 
well tolerated by the patients, however they also reported adverse effects including mild pain, burning sensation, swelling and blisters. These adverse effects associated with PDT were well tolerated, required no additional treatment and resolved spontaneously [25].

Photodynamic therapy of onychomycosis may be tried in patients who, because of their history of internal diseases, cannot be treated with oral antifungal medications, and topical therapy is insufficient. Photodynamic therapy has a fungicidal effect against a number of microorganisms - including dermatophytes (e.g. Trichophyton rubrum), yeast-like fungi (e.g. Candida albicans) and mould fungi (e.g. Aspergillus terreus). Also, the authors of one study point out that the clinical response to PDT was superior in the treatment of mild and moderate mycosis (100\%) to severe toenail onychomycosis $(63.3 \%)$. Importantly, the highest cure rate has been observed in patients with the distal-lateral type of onychomycosis and endonyx onychomycosis which is a relatively rare presentation of the disease [26-28].

The main problem in the treatment of onychomycosis by PDT is inadequate penetration of the drug (photosensitizer) through the nail plate. To overcome this obstacle, the authors of the publications presented above used urea at concentrations in the range of $20-40 \%$ to soften the nail plate and facilitate the entry of the active ingredient into the nail matrix. Other methods improving photosensitizer penetration into the nail plate include mechanical abrasion or complete nail plate removal. The efficacy and success of PDT in the treatment of onychomycosis exhibit a clear correlation with the method of nail plate preparation prior to therapy: the better the rate of penetration into the nail matrix, the better the fungicidal effect $[29,30]$.

Even though the number of publications addressing the treatment of fungal nail infections with PDT is limited, PDT appears to be a promising alternative to conventional antifungal therapy. However, in order to comprehensively evaluate the efficacy of PDT in the treatment of onychomycosis, randomized multi-centre clinical trials are necessary.

\section{CONFLICT OF INTEREST}

The authors declare no conflict of interest. stóp. W omówionych powyżej pracach autorzy wskazują, że pacjenci dobrze tolerowali PDT, jednak zgłaszali również działania niepożądane, takie jak łagodny ból, pieczenie, obrzęki, pęcherze. Wymienione skutki uboczne były dobrze tolerowane, nie wymagały dodatkowego leczenia i ustępowały samoistnie [25].

Terapię fotodynamiczną w leczeniu onychomykozy można wypróbować u pacjentów, którzy ze względów internistycznych nie mogą stosować doustnych leków przeciwgrzybiczych i u których terapia miejscowa jest niewystarczająca. Działa ona grzybobójczo na wiele rodzajów mikroorganizmów, w tym na dermatofity (np. Trichophyton rubrum), grzyby drożdżopodobne (np. Candida albicans) oraz grzyby pleśniowe (np. Aspergillus terreus). Ponadto opublikowano badanie, w którym uzyskano lepszą odpowiedź kliniczną w przypadku zastosowania PDT w leczeniu grzybicy o łagodnym i umiarkowanym nasileniu (100\%) niż grzybicy paznokci stóp o znacznym nasileniu $(63,3 \%)$. Największy odsetek wyleczeń obserwowano u pacjentów z odmianą dystalno-boczną oraz wewnątrzpłytkową, która jest dość rzadka [26-28].

Głównym problemem w leczeniu grzybicy paznokci za pomocą PDT jest niedostateczne wnikanie leku (fotouczulacza) przez płytkę paznokciową. W celu pokonania tej przeszkody autorzy powyższych publikacji stosowali mocznik o stężeniu 20$40 \%$, aby zmiękczyć płytkę i ułatwić substancji czynnej wnikanie do macierzy paznokcia. Inne metody zwiększające przenikanie fotouczulacza w głąb płytki to na przykład mechaniczne ścieranie lub całkowite jej usunięcie. Skuteczność i powodzenie PDT w onychomykozie na pewno zależy od zastosowanej metodyki przygotowania płytki paznokciowej do leczenia - im lek lepiej przenika do macierzy paznokcia, tym lepsze jego działanie grzybobójcze [29, 30].

Mimo że do tej pory pojawiło się niewiele publikacji związanych z wykorzystaniem PDT w leczeniu zakażeń grzybiczych paznokci, wydaje się, że jest to ciekawa alternatywa dla konwencjonalnej terapii przeciwgrzybiczej. Jednak do pełnej oceny skuteczności PDT w leczeniu onychomykozy konieczne są wieloośrodkowe, randomizowane badania kliniczne.

\section{KONFLIKT INTERESÓW}

Autorki deklarują brak konfliktu interesów.

\section{References}

\section{Piśmiennictwo}

1. Vender R., Lynde C., Poulin Y.: Prevalence and epidemiology of onychomycosis. J Cutan Med Surg 2006, 10, 28-33.

2. Szepietowski J., Reich A., Pacan P., Garlowska E., Baran E.: Evaluation of quality of life in patients with toenail onychomycosis by Polish version of an international onychomycosis-specific questionnaire. J Eur Acad Dermatol Venereol 2007, 21 , 491-6.

3. Rich P.: Nail disorders diagnosis and treatment of infectious, inflammatory, and neoplastic nail conditions. Med Clin North Am 1998, 82, 1171-1183.

4. deBerker D., Andre J., Baran R.: Nail biology and nail science. Int J Cosm Sci 2007, 29, 241-275.

5. Westerberg D., Voyack M.: Onychomycosis: current trends in diagnosis and treatment. Am Fam Physician 2013, 88, 762-70. 
6. Wainwright M., Crossley K.: Photosensitising agents - circumventing resistance and breaking down biofilms: a review. Int Biodeterior Biodegrad 2004, 53, 119-126.

7. Kumar S., Kimball A.: New antifungal therapies for the treatment of onychomycosis. Expert Opin Investig Drugs 2009, 18, 727-734.

8. Demidova T., Hamblin M.: Photodynamic therapy targeted to pathogens. Int J Immunopathol Pharmacol 2004, 17, $245-254$.

9. Babilas P., Landthaler M., Szeimies R.: Photodynamic therapy in dermatology. Eur J Dermatol 2006, 16, 340-348.

10. Allison R., Downie G., Cuenca R., Hu X., Childs C., Sibata C.: Photosensitizers in clinical PDT. Photodiagn Photodyn Therap 2004, 1, 27-42.

11. Zhao B., He Y.: Recent advances in the prevention and treatment of skin cancer using photodynamic therapy. Expert Rev Anticancer Ther 2010, 11, 1797-1809.

12. Csanády M., Kiss J.G., Iván L., Jóri J., Czigner J.: ALA (5-aminolevulinic acid)-induced protoporphyrin IX fluorescence in the endoscopic diagnostic and control of pharyngo-laryngeal cancer. Eur Arch Otorhinolaryngol 2004, $261,262-266$.

13. Dietel W., Pottier R., Pfister W., Schleler P., Zinner K.: 5-Aminolaevulinic acid (ALA) induced formation of different fluorescent porphyrins: a study of the biosynthesis of porphyrins by bacteria of the human digestive tract. J Photochem Photobiol B 2007, 86, 77-86.

14. Allison R., Bagnato V., Cuenca R., Downie G.H., Sibata C.H.: The future of photodynamic therapy in oncology. Future Oncol 2006, 2, 53-71.

15. Donnelly R., McCarron P., Tunney M.: Antifungal fotodynamic therapy. Microbiol Res 2008, 163, 1-12.

16. Kübler A.: Photodynamic therapy. Med Laser Appl 2005, 20, 37-45.

17. Donnelly R., McCarron P., Lightowler J., Woolfson A.: Bioadhesive patch-based delivery of 5-aminolevulinic acid to the nail for photodynamic therapy of onychomycosis. J Control Release 2005, 103, 381-392.

18. Kamp H., Tietz H., Lutz M., Piazena H., Sowyrda P., Lademann J., et al.: Antifungal effect of 5-aminolevulinic acid PDT in Trichophyton rubrum. Mycoses 2005, 48, 101-107.

19. Piraccini B., Rech G., Tosti A.: Photodynamic therapy of onychomycosis caused by Trichophyton rubrum. J Am Acad Dermatol 2008, 59, 75-76.

20. Watanabe D., Kawamura C., Masuda Y., Akita Y., Tamada Y., Matsumoto Y.: Successful treatment of toenail onychomycosis with photodynamic therapy. Arch Dermatol 2008, 144, 19-21.

21. Sotiriou E., Koussidou-Eremonti T., Chaidemenos G., Apalla Z., Ioannides D.: Photodynamic therapy for distal and lateral subungual toenail onychomycosis caused by Trichophyton rubrum: preliminary results of a single-centre open trial. Acta Derm Venereol 2010, 90, 216-217.

22. Ghannoum M., Hajjeh R., Scher R., Konnikov N., Gupta A., Summerbell R., et al.: A large-scale North American study of fungal isolates from nails: the frequency of onychomycosis, fungal distribution, and antifungal susceptibility patterns. J Am Acad Dermatol 2000, 43, 641-648.

23. Bhatta A., Huang X., Keyal U., Zhao J.: Laser treatment for onychomycosis: a review. Mycoses 2014, 57, 734-740.

24. Simmons B., Griffith R., Falto-Aizpurua L., Nouri K.: An update on photodynamic therapies in the treatment of onychomycosis. J Eur Acad Dermatol Venereol 2015, 29, 1275-1279.

25. Tardivo J., Wainwright M., Baptista M.: Small scale trial of photodynamic treatment of onychomycosis in São Paulo. J Photochem Photobiol B 2015, 150, 66-68.

26. Gilaberte Y., Aspiroz C., Martes M., Alcalde V., Espinel-Ingroff A., Rezusta A.: Treatment of refractory fingernail onychomycosis caused by nondermatophyte molds with methylaminolevulinate photodynamic therapy. J Am Acad Dermatol 2011, 65, 669-671.

27. Souza L., Souza S., Botelho A.: Distal and lateral toenail onychomycosis caused by Trichophyton rubrum: treatment with photodynamic therapybased on methylene blue dye. An Bras Dermatol 2014, 89, 184-186.

28. Souza L., Souza S., Botelho A.: Endonyx toenail onychomycosis caused by Trichophyton rubrum: treatment with photodynamic therapy based on methylene blue dye. An Bras Dermatol 2013, 88, 1019-1021.

29. de Oliveira G, Antonio J., Antonio C., Tomé F.: The association of fractional CO2 laser 10.600 nm and photodynamic therapy in the treatment of onychomycosis. An Bras Dermatol 2015, 90, 468-471.

30. Menga M., Fabbrocini G., Marasca C., Monfrecola G.: Photodynamic therapy and skin appendage disorders: a review. Skin Appendage Disord 2017, 2, 166-176.

Received: 7.03.2017

Accepted: 9.05.2017

Otrzymano: 7.03.2017 r.

Zaakceptowano: 9.05.2017 r.

How to cite this article

Kalinowska K., Hryncewicz-Gwóźdź A.: Photodynamic therapy in the treatment of onychomycosis - a review. Dermatol Rev/ Przegl Dermatol 2017, 104, 290-299. DOI: https://doi.org/10.5114/dr.2017.68776. 